\title{
KEMAMPUAN BERPIKIR KRITIS MAHASISWA DALAM MENYELESAIKAN SOAL ANALISIS MELALUI PEMBELAJARAN MATEMATIKA BERDASARKAN MASALAH
}

\author{
Fransiskus Gatot Iman Santoso \\ Program Studi Pendidikan Matematika \\ Universitas Katolik Widya Mandala Madiun
}

Email : fransimansantoso@yahoo.com

\begin{abstract}
The research was conducted aimed to determine students' critical thinking skills in solving problems in the course of analysis Geometric Transformations through problem based learning in mathematics. The ability to think critically examined is the ability to solve problems, in this matter of the analysis, the correct procedure and reasoned, correctly draw conclusions based on the facts and the arguments are valid. Students' critical thinking skills in solving problems related to the analysis of subject matter Geometric Transformations, namely translational, half-round, reflection and rotation. This research is descriptive qualitative approach. This study was conducted at Catholic University of Widya Mandala Madiun, and research subjects are students majoring in Mathematics Education Geometric Transformations course overflow Even semester academic year 2011/2012. Data collection techniques in this study using a test method, namely Critical Thinking Test. The results of this study are based on learning mathematics through problem obtained that the average Critical Thinking Skills (CBC) students in solving problems overall analysis on the subject Transformation Geometry of 5.53 and qualifies as being 'critical thinking skills.
\end{abstract}

Keywords: Critial Thinking Skills, Problem Based Learning Mathematics

\section{PENDAHULUAN}

Matematika adalah salah satu mata pelajaran di sekolah, dan juga merupakan mata pelajaran wajib bagi semua peserta didik. Tentu saja para peserta didik diharapkan dapat menguasai konsep-konsep yang dipelajarinya dengan baik. Kurangnya pemahaman dalam matematika mengindikasikan bahwa peserta didik mengalami kesulitan dalam mempelajari konsep matematika. Kesulitan peserta didik dapat mengakibatkan peserta didik tidak mampu untuk berpikir secara logis, analitis, sistematis, kritis, dan kreatif. Untuk mengatasi permasalahan ini, banyak faktor yang harus diperhatikan. Salah satunya faktor dari guru.

Guru merupakan salah satu faktor keberhasilan peserta didik untuk mencapai kemampuan yang maksimal atau terbaik. Guru harus mempersiapkan diri dari rencana pembelajaran sampai dengan tes yang akan digunakan untuk mengukur hasil belajar peserta didik. Sebelum menjadi seorang guru, calon guru ini perlu dididik di perguruan tinggi, supaya calon guru ini mengetahui proses pendidikan dan pembelajaran yang ada. Sehingga, ketika calon guru ini terjun ke lapangan sudah siap menghadapi dunia pendidikan yang ada pada saat ini.

Pada mata pelajaran matematika, calon guru atau mahasiswa pendidikan matematika harus memiliki kemampuan untuk berpikir logis, analitis, sistematis, kritis, dan kreatif. Hal ini dikarenakan, pada matematika dituntut untuk berpikir secara deduktif dan induktif, dan untuk menyelesaikan suatu masalah matematika tidak dengan satu penyelesaian saja. Namun, pada kenyataannya harapan itu belum sepenuhnya terwujud. Hal itu yang sering terjadi pada mahasiswa Pendidikan Matematika Universitas Katolik Widya Mandala Madiun, khususnya pada matakuliah Geometri Transformasi. Apalagi materi yang ada pada matakuliah Geometri Tranformasi disampaikan pada peserta didik sekolah menengah, baik SMP maupun SMA, terutama translasi, refleksi dan rotasi. 
Geometri Transformasi merupakan salah satu matakuliah yang harus ditempuh mahasiswa jurusan Pendidikan Matematika pada tahun kedua semester genap. Deskripsi matakuliah ini adalah mahasiswa mampu memahami transformasi dalam geometri, isometri-isometri seperti translasi, setengah putaran, refleksi, rotasi, serta hasilkali beberapa isometri, hubungannya dan sifatsifatnya, sehingga terampil mengajar di sekolah menengah. Dari deskripsi matakuliah tersebut tersirat bahwa pada perkuliahan Geometri Transformasi harus mengoptimalkan kemampuan berpikir mahasiswa yang di dalamnya terdapat kemampuan berpikir kritis. Berpikir kritis merupakan proses intelektual yang meliputi mengaplikasikan, menganalisis, mensintesis, mengevaluasi informasi, mengob-servasi, menrefleksi, sebagai dasar untuk mempercayai dan melakukan sesuatu (NCTM, 1989). Sedangkan Halpern (1984) menggambarkan berpikir kritis sebagai proses berpikir yang terarah dan bertujuan. Dengan demikian berpikir kritis adalah kegiatan yang beralasan berdasarkan faktafakta dan argumen yang valid sebagai acuan untuk melakukan sesuatu maupun mengambil keputusan.

Pada pembelajaran Geometri Transformasi selama ini, ada kecenderungan lebih menekankan pada aspek menghitung atau menerapkan rumus dan teorema. Misalnya, setelah dosen menjelaskan definisi transformasi, mahasiswa langsung menentukan suatu transformasi dari fungsi tertentu. Dosen jarang bahkan kurang mengajukan pertanyaan analisis untuk melatih kemampuan berpikir kritis mahasiswa dalam membaca definisi. Misalnya, dari definisi transformasi, dosen seharusnya dapat mengajukan pertanyaan, "apakah transformasi bersifat tunggal? Beri penjelasan!" Jika memandang karakteristik materi Geometri Transformasi memungkinkan dosen untuk melatih kemampuan berpikir kritis mahasiswa, salah satunya dengan memberikan pertanyaan analisis. Pertanyaan analisis merupakan pertanyaan yang menuntut mahasiswa memecahkan permasalahan kompleks menjadi bagian-bagian yang lebih sederhana dan menentukan hubungan masing-masing bagian.

Dalam mengembangkan keterampilan kemampuan berpikir kritis peserta didik perlu suatu pembelajaran yang dapat mengembangkan kemampuan tersebut. Banyak pembelajaran yang dapat digunakan untuk mengembangkan kemampuan berpikir kritis, salah satunya melalui pembelajaran matematika berdasarkan masalah. Pembelajaran matematika berdasarkan masalah merupakan pembelajaran matematika yang menggunakan pembelajaran berdasarkan masalah. Dengan menggunakan pembelajaran matematika berdasarkan masalah ini diharapkan kemampuan berpikir kritis mahasiswa dapat berkembang dan terampil. Dengan demikian selama pembelajaran ini, mahasiswa dilatih untuk mengembangkan kemampuan berpikir kritisnya. Selain itu, dengan pertanyaanpertanyaan analisis diharapkan dapat meningkatkan pemahaman dan hasil belajarnya.

\section{TUJUAN PENELITIAN}

Penelitian ini bertujuan untuk mengetahui kemampuan berpikir kritis mahasiswa dalam menyelesaikan soal analisis pada matakuliah Geometri Transformasi melalui pembelajaran matematika berdasarkan masalah.

\section{PEMBATASAN MASALAH}

Mengingat terbatasnya waktu, biaya dan tenaga dalam penelitian ini, serta agar penelitian ini lebih mendalam dan terarah, maka peneliti membatasi :

1. Kemampuan berpikir kritis yang dimaksud adalah kemampuan memecahkan masalah, dalam hal ini soal analisis, dengan prosedur yang benar serta beralasan, menarik 
kesimpulan dengan benar berdasarkan fakta dan argumen yang valid.

2. Tes berpikir kritis yang diberikan pada mahasiswa setelah mahasiswa mengikuti pembelajaran matematika berdasarkan masalah di akhir pokokbahasan.

\section{MANFAAT PENELITIAN}

Adapun manfaat dalam penelitian ini adalah:

1. Hasil penelitian ini diharapkan dapat menjadi masukan bagi universitas dan dosen bahwa untuk menyampaikan materi perkuliahan memperhatikan kemampuan berpikir kritis mahasiswa.

2. Menambah pengetahuan tentang kemampuan berpikir kritis, dan mengaplikasikannya dalam proses pembelajaran.

3. Bagi mahasiswa diharapkan bisa belajar untuk mengembangkan kemampuan berpikir kritis, sehingga bisa digunakan untuk membantunya belajar pada segala bidang dan dapat meningkatkan hasil belajar mahasiswa.

\section{HASIL PENELITIAN}

\section{Pelaksanaan Penelitian}

Sebelum peneliti melakukan penelitian lapangan untuk menyelesaikan permasalahan penelitian dan menganalisa hasil penelitian, peneliti terlebih dahulu menyusun instrumen penelitian yaitu instrumen rencana pembelajaran dan instrumen tes. Instrumen rencana pembelajaran disusun dengan menggunakan pembelajaran berdasarkan masalah (PBM), sedangkan materi perkuliahan diambil dari matakuliah Geometri Transformasi dengan pokokbahasan Translasi, Setengah Putaran, Refleksi dan Rotasi. Setelah instrumen rencana pembelajaran disusun, selanjutnya peneliti menyusun instrumen tes. Instrumen tes yang disusun adalah Tes Berpikir Kritis (TBK) dalam menyelesaikan soal analisis pada matakuliah Geometri Transformasi. TBK ini disusun sebanyak 4 (empat) soal tes, dan masing-masing soal analisis berkaitan dengan materi matakuliah Geometri Transformasi, yaitu Translasi, Setengah putaran, Refleksi dan Rotasi. Adapun subjek penelitiannya adalah mahasiswa jurusan Pendidikan Matematika yang mengampuh matakuliah Geometri Transformasi pada semester Genap Tahun Akademik 2011/2012.

Setelah peneliti menyusun instrumen penelitian, baik instrumen rencana pembelajaran maupun instrumen tes, selanjutnya peneliti melakukan proses pembelajaran sesuai instrumen rencana pembelajaran dengan menggunakan pembelajaran berdasarkan masalah sesuai pokokbahasan pada matakuliah Geometri Transformasi. Di akhir pembelajaran di masing-masing pokokbahasan, subyek penelitian dikenakan tes berpikir kritis.

Setelah subjek penelitian dikenakan tes berpikir kritis dalam menyelesaikan soal analisis pada matakuliah Geometri Transformasi di masing-masing akhir pembelajaran berdasarkan pokokbahasan yang dipelajari, maka diperoleh hasil penelitian :

1. Rataan Kemampuan Berpikir Kritis (KBK) mahasiswa dalam menyelesaikan soal analisis pada pokokbahasan Translasi sebesar 4,80 dan masuk dalam kriteria kemampuan berpikir kritis sedang, dengan sebaran kriteria KBK sebagai berikut :

Tabel 1. Kemampuan Berpikir Kritis (KBK) Mahasiswa pada Pokokbahasan Translasi (S)

Kriteria KBK Jumlah Persentase
Mahasiswa

\begin{tabular}{lcr}
\hline KBK Rendah & 3 & $20,00 \%$ \\
\hline KBK Sedang & 10 & $66,67 \%$ \\
\hline KBK Tinggi & 2 & $13,33 \%$ \\
\hline Jumlah & 15 & $100,00 \%$ \\
\hline
\end{tabular}

2. Rataan Kemampuan Berpikir Kritis (KBK) mahasiswa dalam menyelesaikan soal analisis pada pokokbahasan Setengah Putaran sebesar 5,67 dan masuk dalam kriteria kemampuan berpikir kritis sedang, dengan sebaran kriteria KBK sebagai berikut : 
Tabel 2. Kemampuan Berpikir Kritis (KBK) Mahasiswa pada Pokokbahasan Setengah Putaran (H)

\begin{tabular}{lcc}
\hline Kriteria KBK & $\begin{array}{c}\text { Jumlah } \\
\text { Mahasiswa }\end{array}$ & Persentase \\
\hline KBK Rendah & 4 & $26,67 \%$ \\
\hline KBK Sedang & 6 & $40,00 \%$ \\
\hline KBK Tinggi & 5 & $33,33 \%$ \\
\hline Jumlah & 15 & $100,00 \%$ \\
\hline
\end{tabular}

3. Rataan Kemampuan Berpikir Kritis (KBK) mahasiswa dalam menyelesaikan soal analisis pada pokokbahasan Refleksi sebesar 5,53 dan masuk dalam kriteria kemampuan berpikir kritis sedang, dengan sebaran kriteria KBK sebagai berikut :

Tabel 3. Kemampuan Berpikir Kritis (KBK) Mahasiswa pada Pokokbahasan Refleksi (M)

\begin{tabular}{lcc}
\hline Kriteria KBK & $\begin{array}{c}\text { Jumlah } \\
\text { Mahasiswa }\end{array}$ & Persentase \\
\hline KBK Rendah & 2 & $13,33 \%$ \\
\hline KBK Sedang & 11 & $73,33 \%$ \\
\hline KBK Tinggi & 2 & $13,33 \%$ \\
\hline Jumlah & 15 & $100,00 \%$ \\
\hline
\end{tabular}

4. Rataan Kemampuan Berpikir Kritis (KBK) mahasiswa dalam menyelesaikan soal analisis pada pokokbahasan Rotasi sebesar 6,13 dan masuk dalam kriteria kemampuan berpikir kritis sedang, dengan sebaran kriteria KBK sebagai berikut :

Tabel 4. Kemampuan Berpikir Kritis (KBK) Mahasiswa pada Pokokbahasan Rotasi (R)

\begin{tabular}{lcc}
\hline Kriteria KBK & $\begin{array}{c}\text { Jumlah } \\
\text { Mahasiswa }\end{array}$ & Persentase \\
\hline KBK Rendah & 3 & $20,00 \%$ \\
\hline KBK Sedang & 6 & $40,00 \%$ \\
\hline KBK Tinggi & 6 & $40,00 \%$ \\
\hline Jumlah & 15 & $100,00 \%$ \\
\hline
\end{tabular}

5. Skor masing-masing aspek penilaian kemampuan berpikir kritis dalam menyelesaikan soal analisis pada matakuliah Geometri Transformasi sebagai berikut :

Tabel 5. Skor Aspek Penilaian Ketepatan Sketsa/Gambar

\begin{tabular}{ccccccc}
\hline & \multicolumn{6}{c}{ Jumlah Mahasiswa } \\
\cline { 2 - 7 } Skor & S & H & M & R & Total & $\begin{array}{c}\text { Persen- } \\
\text { tase }\end{array}$ \\
\hline 0 & 0 & 1 & 0 & 0 & 1 & $1,67 \%$ \\
\hline 1 & 15 & 8 & 6 & 9 & 38 & $63,33 \%$ \\
\hline 2 & 0 & 2 & 6 & 4 & 12 & $20,00 \%$ \\
\hline
\end{tabular}

\begin{tabular}{cccccrc}
\hline 3 & 0 & 4 & 3 & 2 & 9 & $15,00 \%$ \\
\hline Total & 15 & 15 & 15 & 15 & 60 & $100,00 \%$ \\
\hline
\end{tabular}

Tabel 6. Skor Aspek Penilaian Keruntutan Langkah Pengerjaan

\begin{tabular}{ccccccc}
\hline & \multicolumn{6}{c}{ Jumlah Mahasiswa } \\
\cline { 2 - 7 } Skor & S & H & M & R & Total & $\begin{array}{c}\text { Persen- } \\
\text { tase }\end{array}$ \\
\hline 0 & 1 & 3 & 2 & 3 & 9 & $15,00 \%$ \\
\hline 1 & 3 & 2 & 3 & 1 & 9 & $15,00 \%$ \\
\hline 2 & 11 & 10 & 10 & 11 & 42 & $70,00 \%$ \\
\hline Total & 15 & 15 & 15 & 15 & & 100,00 \\
$\%$
\end{tabular}

Tabel 7. Skor Aspek Penilaian Kebenaran Jawaban Setiap Langkah

\begin{tabular}{ccccccc}
\hline & \multicolumn{6}{c}{ Jumlah Mahasiswa } \\
\cline { 2 - 7 } & $\mathrm{S}$ & $\mathrm{H}$ & $\mathrm{M}$ & $\mathrm{R}$ & Total & $\begin{array}{c}\text { Persen- } \\
\text { tase }\end{array}$ \\
\hline 0 & 3 & 3 & 2 & 3 & 11 & $18,33 \%$ \\
\hline 1 & 10 & 7 & 12 & 6 & 35 & $58,33 \%$ \\
\hline 2 & 2 & 5 & 1 & 6 & 14 & $23,33 \%$ \\
\hline Total & 15 & 15 & 15 & 15 & 60 & $100,00 \%$ \\
\hline
\end{tabular}

Tabel 8. Skor Aspek Penilaian Kebenaran Menyimpulkan Pernyataan

\begin{tabular}{crrrrrrr}
\hline \multirow{2}{*}{ Skor } & \multicolumn{6}{c}{ Jumlah Mahasiswa } \\
\cline { 2 - 7 } & S & H & M & R & Total & $\begin{array}{c}\text { Persen- } \\
\text { tase }\end{array}$ \\
\hline 0 & 11 & 10 & 14 & 8 & 43 & $71,67 \%$ \\
\hline 1 & 4 & 5 & 1 & 7 & 17 & $28,33 \%$ \\
\hline Total & 15 & 15 & 15 & 15 & 60 & $100,00 \%$ \\
\hline
\end{tabular}

Tabel 9. Skor Aspek Penilaian Argumen

\begin{tabular}{crrrrrr}
\hline \multirow{2}{*}{ Skor } & \multicolumn{6}{c}{ Jumlah Mahasiswa } \\
\cline { 2 - 7 } & S & H & M & R & Total & $\begin{array}{c}\text { Persen- } \\
\text { tase }\end{array}$ \\
\hline 0 & 3 & 3 & 2 & 3 & 11 & $18,33 \%$ \\
\hline 1 & 10 & 7 & 8 & 3 & 28 & $46,67 \%$ \\
\hline 2 & 2 & 5 & 5 & 9 & 21 & $35,00 \%$ \\
\hline Total & 15 & 15 & 15 & 15 & 60 & $100,00 \%$ \\
\hline
\end{tabular}

6. Rataan Kemampuan Berpikir Kritis (KBK) mahasiswa dalam menyelesaikan soal analisis secara keseluruhan pada matakuliah Geometri Transformasi sebesar 5,53 dan masuk dalam kriteria kemampuan berpikir kritis sedang, dengan sebaran kriteria KBK sebagai berikut :

Tabel 10. Kemampuan Berpikir Kritis (KBK) Mahasiswa pada Matakuliah Geometri Transformasi

\begin{tabular}{ccc}
\hline Kriteria KBK & $\begin{array}{c}\text { Jumlah } \\
\text { Mahasiswa }\end{array}$ & Persentase \\
\hline KBK Rendah & 3 & $20,00 \%$ \\
\hline
\end{tabular}




\begin{tabular}{lrr}
\hline KBK Sedang & 11 & $73,33 \%$ \\
\hline KBK Tinggi & 1 & $6,67 \%$ \\
\hline Jumlah & 15 & $100,00 \%$ \\
\hline
\end{tabular}

\section{PEMBAHASAN}

Berdasarkan hasil penelitian melalui pembelajaran matematika berdasarkan masalah diperoleh pada matakuliah Geometri Transformasi kemampuan berpikir kritis (KBK) mahasiswa dalam menyelesaikan soal analisis pada pokokbahasan Translasi sebesar 4,80, pada pokokbahasan Setengah Putaran sebesar 5,67, pada pokokbahasan Refleksi sebesar 5,53, pada pokokbahasan Rotasi sebesar 6,13 serta pada matakuliah Geometri Transformasi sebesar 5,53 dan masuk dalam kriteria kemampuan berpikir kritis sedang. Hal ini menunjukkan bahwa pembelajaran matematika berdasarkan masalah sudah dengan baik dalam melatih mahasiswa untuk berpikir kritis dalam menyelesaikan soal analisis yang diajukan selama pembelajaran berlangsung. Hasil ini menambah kebermaknaan pembelajaran berdasarkan masalah yang di dalam pembelajaran ini peserta didik mengerjakan masalah yang diajukan oleh pendidik, menyusun pengetahuan, mengembangkan inkuiri dan ketrampilan berpikir. Kemampuan berpikir kritis mahasiswa di dalam pembelajaran berdasarkan masalah dilatih selama pembelajaran berlangsung dengan keterlibatan mahasiswa selama pembelajaran, melakukan investigasi terhadap masalah yang diajukan, bekerja bersama dalam menyelesaikan masalah yang diajukan, saling tanya jawab dan berdiskusi antar mahasiswa. Situasi seperti ini menghadapkan mahasiswa untuk mampu menemukan masalah, meneliti dan menyelesaikan masalah, sehingga mahasiswa dituntut aktif selama pembelajaran berlangsung. Di samping itu, mahasiswa diminta untuk mendesain, mengembangkan serta mempresentasikan artefak dan exhibit, selanjutnya mempresentasikan atau memamerkan hasil karya mahasiswa di depan kelas.
Kebermaknaan ini dalam pembelajaran matematika berdasarkan masalah membuat kemampuan berpikir kritis mahasiswa dalam menyelesaikan soal analitis pada matakuliah Geometri Transformasi pada kriteria sedang. Hal ini didukung dengan persentase kemampuan berpikir kritis mahasiswa yang mempunyai kriteria sedang dan tinggi sebesar $80 \%$ pada pokokbahasan Translasi, sebesar $73,33 \%$ pada pokokbahasan Setengah Putaran, sebesar $83,67 \%$ pada pokokbahasan Refleksi, sebesar $80,00 \%$ pada pokokbahasan Rotasi dan sebesar $80,00 \%$ pada matakuliah Geometri Transformasi.

Berdasarkan aspek penilaian kemampuan berpikir kritis dalam menyelesaikan soal analisis pada matakuliah Geometri Transformasi pada tabel 5 yaitu aspek penilaian ketepatan sketsa/gambar menunjukkan bahwa 65\% mahasiswa (dari skor 0 dan skor 1) masih kurang tepat membuat sketsa/gambar dalam menyelesaikan permasalahan yang diajukan. Hanya 15\% mahasiswa saja yang tepat membuat sketsa/gambar dalam menyelesaikan permasalahan yang diajukan pada pembelajaran berdasarkan masalah. Hal ini disebabkan mahasiswa kurang terbiasa dalam menyelesaikan permasalahan yang diajukan dengan menggunakan sketsa/gambar. Padahal selama proses pembelajaran berdasarkan masalah dari tahap pertama pembelajaran sampai dengan tahap akhir pembelajaran, terutama bagian artefak dan exhibit, mahasiswa diwajibkan untuk mendesain artefak dan exhibit. Selain itu, mahasiswa diwajibkan mengembangkan serta mempresentasikan artefak dan exhibit. Selanjutnya mahasiswa mempresentasikan atau memamerkan hasil karya mahasiswa di depan kelas. Sehingga berakibat, kebermaknaan pembelajaran berdasarkan masalah kurang dimaknai dengan baik oleh peserta didik.

Berdasarkan aspek penilaian kemampuan berpikir kritis dalam menyelesaikan soal analisis pada matakuliah 
Geometri Transformasi pada tabel 6 yaitu aspek penilaian keruntutan langkah pengerjaan menunjukkan bahwa $70 \%$ mahasiswa sudah dengan baik dan runtut dalam langkah pengerjaan permasalahan yang diajukan pada pembelajaran berdasarkan masalah. Hanya $30 \%$ mahasiswa (pada skor 0 dan skor 1) yang kurang baik dan kurang runtut dalam langkah pengerjaan permasalahan yang diajukan pada pembelajaran berdasarkan masalah. Hal ini dikarenakan mahasiswa diwajibkan menyelesaikan permasalahan yang diajukan pada pembelajaran berdasarkan masalah. Di dalam pembelajaran berdasarkan masalah, mahasiswa dilatih selama pembelajaran berlangsung dengan keterlibatan mahasiswa selama pembelajaran, melakukan investigasi terhadap masalah yang diajukan, bekerja bersama dalam menyelesaikan masalah yang diajukan, saling tanya jawab dan berdiskusi antar mahasiswa. Situasi seperti ini menghadapkan mahasiswa untuk mampu menemukan masalah, meneliti dan menyelesaikan masalah, sehingga mahasiswa dituntut aktif selama pembelajaran berlangsung. Sehingga keruntunan langkah pengerjaan permasalahan yang diajukan pada diri mahasiswa tertanam dengan baik dalam pembelajaran berdasarkan masalah.

Berdasarkan aspek penilaian kemampuan berpikir kritis dalam menyelesaikan soal analisis pada matakuliah Geometri Transformasi pada tabel 7 yaitu aspek penilaian kebenaran jawaban setiap langkah menunjukkan bahwa 76,67\% mahasiswa (dari skor 0 dan skor 1) masih kurang tepat untuk kebenaran jawaban setiap langkahnya dalam menyelesaikan permasalahan yang diajukan pada pembelajaran berdasarkan masalah. Hanya $23,33 \%$ mahasiswa saja yang tepat untuk kebenaran jawaban setiap langkahnya dalam menyelesaikan permasalahan yang diajukan pada pembelajaran berdasarkan masalah. Hal ini dikarenakan sebagian besar mahasiswa kurang teliti dan kurang memeriksa kembali penyelesaian dalam menyelesaikan permasalahan yang diajukan pada pembelajaran berdasarkan masalah. Hanya sebagian kecil saja mahasiswa yang teliti dan kurang memeriksa kembali penyelesaian dalam menyelesaikan permasalahan yang diajukan pada pembelajaran berdasarkan masalah. Hal ini berakibat pada aspek penilaian kemampuan berpikir kritis dalam menyelesaikan soal analisis pada matakuliah Geometri Transformasi pada tabel 8 yaitu aspek penilaian kebenaran menyimpulkan pernyataan menunjukkan bahwa $71,67 \%$ mahasiswa yang tidak benar dalam menyimpulkan pernyataan dalam menyelesaikan permasalahan yang diajukan pada pembelajaran berdasarkan masalah. Hanya 28,33\% mahasiswa saja yang benar dalam menyimpulkan pernyataan dalam menyelesaikan permasalahan yang diajukan pada pembelajaran berdasarkan masalah.

Berdasarkan aspek penilaian kemampuan berpikir kritis dalam menyelesaikan soal analisis pada matakuliah Geometri Transformasi pada tabel 9 yaitu aspek penilaian argumen menunjukkan bahwa 65,00\% mahasiswa masih kurang untuk berargumen dengan baik dan benar dalam menyelesaikan permasalahan yang diajukan pada pembelajaran berdasarkan masalah. Hanya 35,00\% mahasiswa saja yang dapat berargumen dengan baik dan benar dalam menyelesaikan permasalahan yang diajukan pada pembelajaran berdasarkan masalah. Hal ini disebabkan mahasiswa kurang terbiasa dalam menyelesaikan permasalahan yang diajukan untuk berargumen dengan baik dan benar. Padahal selama proses pembelajaran berdasarkan masalah dari tahap pertama pembelajaran sampai dengan tahap akhir pembelajaran, terutama bagian artefak dan exhibit, mahasiswa diwajibkan untuk mendesain artefak dan exhibit. Hal ini dapat digunakan mahasiswa untuk saling berargumen dan menyampaikan pendapat antar sesama mahasiswa dalam satu kelompok. Selain itu, 
mahasiswa diwajibkan mengembangkan serta mempresentasikan artefak dan exhibit. Selanjutnya mahasiswa mempresentasikan atau memamerkan hasil karya mahasiswa di depan kelas. Sehingga berakibat, kebermaknaan pembelajaran berdasarkan masalah kurang dimaknai dengan baik oleh peserta didik.

\section{SIMPULAN DAN SARAN}

\section{Simpulan}

Berdasarkan hasil penelitian, maka dapat disimpulkan bahwa kemampuan berpikir kritis peserta didik dalam menyelesaikan soal analisis pada Geometri Transformasi melalui pembelajaran berdasarkan masalah sebesar 5,53 dan masuk dalam kriteria kemampuan berpikir kritis sedang.

\section{Saran}

Berdasarkan kesimpulan diatas, maka peneliti dapat memberikan saran sebagai berikut :

1. Bagi pendidik

a. Untuk memperhatikan kemampuan berpikir kritis peserta didiknya supaya dapat menyelesaikan masalah-masalah yang berhubungan dengan analisis.

b. Dapat menggunakan pembelajaran matematika berdasarkan masalah sebagai alternatif pembelajaran guna melatih dan mengembangkan kemampuan berpikir kritis peserta didik dalam menyelesaikan soal analisis.

2. Bagi peserta didik

Untuk selalu melatih kemampuan berpikir kritisnya dalam menyelesaikan soal analisis melalui berbagai bentuk pembelajaran yang digunakan oleh pendidik.

\section{DAFTAR PUSTAKA}

Arends, R. I. 2004. Learning to Teach. $6^{\text {th }}$ Edition. Boston:Mc Graw Hill

Halpern, F. Diane. 1984. Thought and Knowledge an Introduction ti Critical Thinking. New Jersey:Lawrence Erlbaum Asspciate Inc.

NCTM. 1989. Curriculum and Evaluation Standards for School Mathematics. Reston, VA: NCTM.

Rosyidi, Abdul Haris. 2011. Kemampuan Berpikir Kritis Mahasiswa dalam Menyelesaikan Soal Analisis Berkaitan dengan Luas Daerah Bidang dan Volum Benda Putar. Surabaya:Proseding Seminar Nasional Matematika Unesa

Trianto. 2009. Mengembangkan Model Pembelajaran Berdasarkan Masalah. Jakarta : Prestasi Pustaka 